\title{
Biologic Activity of a Dinuclear Pd(II)-Spermine Complex Toward Human Breast Cancer
}

\author{
Sónia M. Fiuza ${ }^{1}$, Jon Holy ${ }^{2}$, \\ Luis A. E. Batista de Carvalho' ${ }^{1}$ and \\ Maria P. M. Marques ${ }^{1,3}$ \\ ${ }^{1}$ Química-Física Molecular, Departamento de Química, FCTUC, \\ Universidade de Coimbra, P-3004-535 Coimbra, Portugal \\ ${ }^{2}$ Department of Anatomy and Cell Biology, University of Minnesota \\ School of Medicine, Duluth, 1035 MN 55812, USA \\ ${ }^{3}$ Departmento de Bioquímica, FCTUC, Universidade de Coimbra, Ap. \\ 3126, P-3001-401 Coimbra, Portugal \\ *Corresponding author: Sónia M. Fiuza, sonia.mfiuza@gmail.com
}

A dinuclear palladium-based complex ( $\left.\mathbf{P d}_{2}-\mathrm{Spm}\right)$ was synthesized and compared with cisplatin (cDDP) on two different human breast cancer cell lines (MCF-7 and MDA-MB-231) as well as toward an untransformed cell line (BJ fibroblasts). The results obtained show that $\mathbf{P d}_{\mathbf{2}}$-Spm is more effective against the estrogen receptors $[E R(-)]$ cell line MDA-MB-231, while cDDP displayed better results for the $E R(+)$ MCF-7 cell line. It was shown that, like cDDP, $\mathbf{P d}_{2}-\mathrm{Spm}$ triggers phosphorylation of $H 2 A X$, indicating that this compound damages DNA. Apart from $\mathrm{DNA}, \mathbf{P d}_{\mathbf{2}}-\mathrm{Spm}$ also targets the cytoskeleton having a greater impact on cell morphology than cDDP. $\mathbf{P d}_{2}-\mathrm{Spm}$ and cDDP have opposite antiproliferative activities in the presence of the PI3K inhibitor wortmannin. Furthermore, $\mathbf{P d}_{2}-\mathbf{S p m}$ at an optimized concentration displays a rapid antiproliferative effect as opposed to cDDP, which seems to have a slower kinetics. The results point to a distinct mechanism of action for each of these complexes, which may explain their synergistic action when coadministrated.

Key words: gamma-H2AX, human breast cancer, $\mathrm{Pd}(\mathrm{II})$ complex, polynuclear, spermine, wortmannin

Received 5 January 2010, revised 11 June 2010 and accepted for publication 31 December 2010

Breast cancer is the most common cancer among women and one of the main causes of death in women in Portugal (1-3). Evolution of human breast cancer is related with cells' dependence on ovarian estrogens, with the presence $(+)$ or absence $(-)$ of estrogen receptors (ER) being an important marker for the prognosis and choice of therapeutic strategies. Generally, patients suffering from $E R(+)$ breast cancer have better life prospects than those with breast cancer lacking ER expression, which tend to be more aggres- sive (66-month survival rate) (4). For advanced stages of breast cancer, chemotherapy becomes an important therapeutic option. While cisplatin [cis-diamminedichloroplatinum(II), cis- $\mathrm{Pt}\left(\mathrm{NH}_{3}\right)_{2} \mathrm{Cl}{ }_{2}$, cDDP, Figure $1 \mathrm{~A}]$ is still among the most widely used drugs in cancer chemotherapy, patients that are treated with cDDP suffer from severe side-effects and, very often, develop resistance mechanisms. These facts urge for the pursuit of improved antitumor agents, displaying lower toxicity coupled to a broader spectrum of activity. Hundreds of new cisplatin-based compounds have been synthesized to date, to overcome cisplatin's harmful side-effects while retaining efficacy. Other inorganic agents, comprising different transition metals, have also been studied (5). Pd(II) complexes are particularly interesting because although structurally similar to Pt(II), their reactivity is fairly distinct. In fact, reactions involving $P d(I I)$ are reported to be about $10^{4}-10^{5}$ faster than those with Pt(II) $(6,7)$. This increased lability is thought to be the main reason for the biologic inactivity of some $\mathrm{Pd}(\mathrm{II})$ agents, namely, cis-diamminedichloropalladium(II) (cis$\left.\mathrm{Pd}\left(\mathrm{NH}_{3}\right)_{2} \mathrm{Cl}_{2}, \mathrm{cDDPd}\right)$. However, despite the initial belief that $\mathrm{Pd}(\mathrm{II})$ compounds were inactive as antineoplastic agents, many have been synthesized and shown to be not only more active than cisplatin (8-10) but also more effective than their Pt(II) counterparts (11-13).

Because it is broadly accepted that one of the main targets of this type of metal-based compounds is DNA, new strategies to increase their activity range are strongly correlated to their ability to act through a distinct mechanism than cisplatin, even if aiming at the same molecular target. In this regard, multinuclear Pt(II) polyamine complexes comprising cisplatin-like moieties (either $\left[\mathrm{PtCl}\left(\mathrm{NH}_{3}\right)_{2}\right]$ or $\left.\left[\mathrm{PtCl}_{2}\left(\mathrm{NH}_{3}\right)\right]\right)$ linked by variable length alkanediammine chains were synthesized and constitute a promising class of anticancer agents (14-16). In fact, the trinuclear complex BBR3464 ([(trans-PtCl $\left.\left(\mathrm{NH}_{3}\right)_{2}\right)_{2}\left(\mu\right.$-trans-Pt $\left.\left.\left.\left(\mathrm{NH}_{3}\right)_{2}\left(\mathrm{NH}_{2}\left(\mathrm{CH}_{2}\right)_{6} \mathrm{NH}_{2}\right)_{2}\right)\right]\left(\mathrm{NO}_{3}\right)_{4}\right)$ has already entered phase II clinical trials (17). These multinuclear Pt(II) polyamine chelates display DNA binding properties distinct from those of cisplatin, because their flexible linkers allow the formation of 'long-distance' inter- and intrastrand cross-links unavailable to conventional Pt(II) drugs such as cisplatin or its mononuclear first- and second-generation analogs (18). The biogenic polyamine spermine is able to chelate with metal ions providing such flexible linkers and conferring hydrophobic character to the molecule which is important for drug uptake. In addition, it was previously shown that spermine synergizes with cDDP by modulating cDDP influx through cell membranes (19).

The present work reports a study on the biologic activity of a dinuclear $\mathrm{Pd}(\mathrm{II})$ chelate with a spermine ligand $(20), \quad \mathrm{Pd}_{2}-\mathrm{Spm}$ $\left[\left(\mathrm{PdCl}_{2}\right)_{2}(\mathrm{spm}), \quad\left(\mathrm{spm}=\right.\right.$ spermine, $\left.\left.\quad \mathrm{H}_{2} \mathrm{~N}\left(\mathrm{CH}_{2}\right)_{3} \mathrm{NH}\left(\mathrm{CH}_{2}\right)_{4} \mathrm{NH}\left(\mathrm{CH}_{2}\right)_{3} \mathrm{NH}_{2}\right)\right)$ - Figure 1B]. toward two different human breast cancer cell 
Fiuza et al.

A<smiles>N[PH](N)(Cl)Cl</smiles>

B<smiles>Cl[P]1(Cl)NCCCN1CCCN1CCCN[P+]1(Cl)Cl</smiles>

C<smiles>Cl[Te]1(Cl)NCCCN1</smiles>

D $\mathrm{H}_{2} \mathrm{~N}-\left(\mathrm{CH}_{2}\right)_{3}-\mathrm{NH}-\left(\mathrm{CH}_{2}\right)_{4}-\mathrm{NH}-\left(\mathrm{CH}_{2}\right)_{3}-\mathrm{NH}_{2}$

Figure 1: Schematic representation of the compounds used in this study. (A) Cisplatin (cDDP); (B) $\left(\mathrm{PdCl}_{2}\right)_{2} \mathrm{Spm}\left(\mathrm{Pd}_{2}-\mathrm{Spm}\right) ;(\mathrm{C})$ $\mathrm{Pd}(\mathrm{dap}) \mathrm{Cl}_{2}$; and (D) Spermine (Spm).

lines - MCF-7 cell line with functional ER and MDA-MB-231 which lacks the expression of $E R$ and is therefore insensitive to estrogen and antiestrogens drugs such as tamoxifen and benzothiophene (21). The BJ cell line was used as a non-tumorigenic model. This study comprises the evaluation of the Pd(II) complex antiproliferative profile, its capacity to induce DNA damage, and the importance of DNA repair on this induced damage.

\section{Methods and Materials}

All chemicals and solvents used were reagent grade (Sigma and Aldrich, Sintra, Portugal) and were used without further purification. $\mathrm{K}_{2} \mathrm{PdCl}_{4}(98 \%)$, spermine $(\geq 97 \%)$, and cisplatin $(\geq 99.9 \%)$ were acquired from Sigma (Sintra, Portugal) and used without further purification. Cisplatin was solubilized in PBS and filtered prior to cell treatment. Wortmannin $(\geq 98 \%)$ was obtained from Sigma as powder, reconstituted in DMSO, and stored at $-20{ }^{\circ} \mathrm{C}$. This solution was diluted in water prior to addition to the cell cultures so that the DMSO concentration never exceeded 1\% ( $/ / v)$. DMEM-HG medium containing phenol red and lacking sodium bicarbonate (99.5\%) were obtained from Sigma. Fetal bovine serum (FBS; Gibco, Alfagene, Carcavelos, Portugal) and Trypsin-EDTA (0.05\%) were obtained from Gibco. The primary monoclonal anti- $\beta$-tubulin antibody E7 was from Developmental Studies Hybridoma Bank, lowa City, IA, USA, the goat anti-mouse secondary fluorescein-conjugated antibodies from Jackson ImmunoResearch, West Grove, PA, USA, Hoechst 33258 from Sigma, and rhodamine-conjugated phalloidin from Molecular Probes, Eugene, OR, USA. SDS-polyacrylamide gels and nitrocellulose membranes were purchased from Bio-Rad, Hercules, CA, USA. The primary monoclonal antibody anti- $\gamma \mathrm{H} 2 \mathrm{AX}$ was obtained from Upstate, Cell Signalling, Piscataway, NJ, USA and the ECF detection system from Amersham, UK.

\section{Synthesis}

$\mathrm{Pd}_{2}$-Spm synthesis was carried out according to Codina et al. (20). Briefly, $2 \mathrm{mmol}$ of $\mathrm{K}_{2} \mathrm{PdCl}_{4}$ were dissolved in a minimal amount of water, and an aqueous solution containing $1 \mathrm{mmol}$ of spermine was added dropwise under continuous stirring (which was kept for about $24 \mathrm{~h})$. This reaction yielded a yellow powder of $\left(\mathrm{PdCl}_{2}\right)_{2}(\mathrm{spm})$ which was filtered and washed with pure acetone. The elemental analysis was carried out at the Atlantic Microlab, Inc., Georgia, USA. The vibrational analysis, carried out by both Raman and Inelastic Neutron Scattering (INS) spectroscopies, evidenced the presence of the bands characteristic of these particular metal-amine chelates $v_{s(\mathrm{Pd}-\mathrm{N})}=501 / \mathrm{cm} ; \quad v_{\text {as(Pd-N })}=449 / \mathrm{cm} ; \quad v_{\mathrm{s}(\mathrm{Pd}-\mathrm{Cl})}=324 / \mathrm{cm} ; \quad v_{\text {as }(\mathrm{Pd}-\mathrm{Cl})}=$

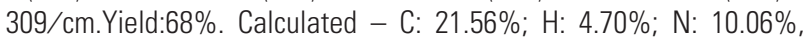
Cl: $25.46 \%$ and Found: C: $21.22 \% ; \mathrm{H}: 4.68 \% ; \mathrm{N}: 9.60 \%, \mathrm{Cl}$ : $25.88 \% . \mathrm{Pd}_{2}$-Spm was solubilized in PBS and filtered prior to cell treatment.

\section{Cell lines and cell culture}

The MDA-MB-231 cell line (human Caucasian estrogen-independent breast adenocarcinoma) was purchased from the European Collection of Cell Cultures (ECCAC, Salisbury, UK), while the BJ line was obtained from the American Type Culture Collection (ATCC, Manassas, VA, USA). The MCF-7 line (human Caucasian estrogen-dependent breast adenocarcinoma) was kindly made available by the Biochemistry Service of the Faculty of Medicine of the University of Coimbra.

All the cell lines were cultured as monolayers in tissue culture petri dishes, at $37{ }^{\circ} \mathrm{C}$, in a humidified atmosphere of $5 \% \mathrm{CO}_{2}$. Cultures were grown in DMEM-HG medium containing phenol red supplemented with $10 \%(\mathrm{~V} / \mathrm{V})$ fetal bovine serum and sodium bicarbonate. Trypsin-EDTA was used for passaging cells at near-confluence. Under these growing conditions, the duplication time was found to be 26 , 51, and $167 \mathrm{~h}$ for the MDA-MB-231, MCF-7, and BJ cell lines, respectively, [which is in accordance with previous findings (21)].

\section{Proliferation assays}

\section{Simple proliferation assays}

For the determination of the antiproliferative activity of the $\mathrm{Pd}_{2}$ Spm complex, cultures were established in 24-well plates ( $1 \mathrm{~mL} /$ well) at a density of $5 \times 10^{3}$ cells $/ \mathrm{mL}$ and were allowed to attach for about $24 \mathrm{~h}$. Triplicate cultures were treated for different incubation periods and different concentrations of the test compounds (from 1 to $16 \mu \mathrm{M}$ ). Because the three cell lines studied have different population doubling times, the results were compared both for equal time-points (an early 24-h time-point and a mid-time-point of $72 \mathrm{~h}$ ), as well as a late time-point that reflected a similar number of population doublings for each cancer line labout four population doublings after the addition of the compounds, corresponding to the 96-h time-point for MDA-MB-231 and $168 \mathrm{~h}$ for MCF-7). Because of the low growth rate of the non-tumorigenic BJ cells, the 168-h time-point simply comprises one population doubling, and therefore, these results are interpreted as cell survival. At the end of each time-point, the growth media was aspirated, the wells were washed, and the cells were fixed with ice-cold methanol $[1 \%$ $(v / v)$ acetic acid] and stored at $-20{ }^{\circ} \mathrm{C}$. After this fixation process, cell proliferation was evaluated through the Sulforhodamine B (SRB) staining assay that determines cellular protein content interpreted as cell number (22-26). 
Biologic Activity of a Dinuclear Pd(II)-Spermine Complex

Two different schedules of drug treatment were used: (i) continuous exposure of the cells to the compounds under study; (ii) non-continuous exposure, having the drugs removed and replaced by fresh media, after one population doubling.

Cisplatin was used in all experiments for comparison purposes. The results obtained for $\mathrm{Pd}_{2}$-Spm and cDDP can be compared in terms of potency, for either equal doses of each agent or using twice the concentration of cDDP for each $\mathrm{Pd}_{2}$-Spm dosage, i.e., considering an equivalent number of metals centers.

\section{Proliferation assays in the presence of wortmannin}

The proliferation assays in the presence of wortmannin were performed in the continuous presence of the inhibitor. All the cells, including the control samples, were preincubated with $10 \mu \mathrm{M}$ wortmannin for about $1 \mathrm{~h}$ prior to administration of the test compounds. These experimental conditions were based on a previously published study (27).

\section{Proliferation assays of $\mathbf{P d}_{\mathbf{2}}$-Spm combined with cDDP}

For this experiment, the cells were seeded in a 24-well plate (1 $\mathrm{mL} /$ well) at a density of $5 \times 10^{3}$ cells $/ \mathrm{mL}$ and were allowed to attach for $24 \mathrm{~h}$. To test for two different drugging schedules, (i) the cells were exposed simultaneously to either 2 or $4 \mu \mathrm{M}$ of each compound (ii) the cells were treated with an initial dose of $\mathrm{Pd}_{2}$ Spm $(4 \mu \mathrm{M})$ for $24 \mathrm{~h}$, after which the media was removed and the wells were washed with PBS. Fresh media was added, and cisplatin was administered at 1 and $2 \mu \mathrm{M}$ concentrations. The end-points were collected from this time forward.

For the experiment where the compounds were coadministrated, the drug interactions were assessed using the methods described by Berenbaum (28). Synergism was evaluated using the formula (29):

$$
\frac{a}{A}+\frac{b}{B}=1
$$

where $A$ and $B$ represent the $I_{50}$ values of compounds $\mathrm{Pd}_{2}-S p m$ and cDDP, respectively, $a$ is the $\mathrm{IC}_{50}$ calculated for the coadministration and $b$ is the concentration $(\mu \mathrm{M})$ of cDDP used in combination with $\mathrm{Pd}_{2}-\mathrm{Spm}$. If $I<1$, there is synergy; if $I=1$, there is an additive effect only and when $/>1$, an antagonist interaction occurs.

\section{Presentation of the proliferation assay results and statistical analysis}

Proliferation data were obtained from experiments in which both controls and cultures exposed to the test compounds were established and processed in parallel. All the results are expressed in terms of percentages of the control value. The $I_{50}$ values were calculated from dose-response studies for each compound in a range of $0-50 \mu \mathrm{M}$ (data not shown). The data presented are an average of at least three independent experiments, with the corresponding standard error of the mean (SEM) having been calcu- lated in all cases. The statistical significance of the differences from the control was assessed using Newman-keuls post-test. All the calculations were performed with the GraphPad Prism 4 Software (GraphPad Software, La Jolla, CA, USA).

\section{Immunocytochemistry}

MDA-MB-231 were grown on glass coverslips and treated with 2 and $4 \mu \mathrm{M}$ of both $\mathrm{Pd}_{2}-\mathrm{Spm}$ and cDDP. After a 24-h exposure time, the media was removed, the wells were washed with PBS, and the cells were fixed in the appropriate solution. For microtubules labeling, the cells were fixed in ice-cold methanol and kept at $-20^{\circ} \mathrm{C}$ for an hour. After rehydration in PBST $(50 \mathrm{~mm}$ Tris- $\mathrm{HCl}, \mathrm{pH} 8$; $154 \mathrm{~mm} \mathrm{NaCl}$ and $0.1 \%$ Tween 20), coverslips were blocked with $1 \%$ powdered milk in PBST for 30 min at $37^{\circ} \mathrm{C}$ and subsequently washed three times with PBST for 5 min. The primary monoclonal anti- $\beta$-tubulin antibody E7 was then incubated for $1 \mathrm{~h}$ at $37^{\circ} \mathrm{C}$. Following primary antibody incubation, coverslips were washed three times with PBST for 5 min each and treated with the goat antimouse secondary fluorescein-conjugated antibodies. All secondary antibodies were diluted 1:50 with PBST and used at $37^{\circ} \mathrm{C}$ for $1 \mathrm{~h}$. DNA was fluorescently stained with $5 \mu \mathrm{g} / \mathrm{mL}$ Hoechst 33258. After a final set of three washes with PBST of 5 min each, coverslips were mounted in antifade medium (90\% glycerol, 10\% CAPS ( $N$-cyclohexyl-3-aminopropanesulfonic acid) buffer, $0.1 \%$ phenylenediamine, pH 9) to retard photobleaching and examined and photographed with a Nikon TE-300 inverted epifluorescence microscope equipped with a Photometrics CoolSnap ES CCD camera.

For microfilament labeling, the same procedure was carried out, with the exception that the cells were fixed with $4 \%$ paraformaldehyde at $4{ }^{\circ} \mathrm{C}$ and were labeled with rhodamine-conjugated phalloidin for $2 \mathrm{~h}$ at $37^{\circ} \mathrm{C}$, according to manufacturer's instructions.

\section{Western blot analysis}

Phosphorylated H2AX histone $(\gamma-\mathrm{H} 2 \mathrm{AX})$ quantity was analyzed by Western blot. Cell culture petri dishes $\left(25 \mathrm{~cm}^{2}\right)$ with confluent MDA-MB-231 cells were exposed for $6 \mathrm{~h}$ to $20 \mu \mathrm{M}$ of each $\mathrm{Pd}_{2-}$ Spm and CDDP and the same amount of vehicle solution (PBS) added to the control cells. The cells were harvested, and Laemmli buffer (20\% SDS, 0.1\% bromphenol blue dye, $13 \mathrm{M}$ glycerol, $1 \mathrm{~mL} \beta$-mercaptoethanol) was added at a proportion of $1 \times 10^{5}$ cells $/ 10 \mu \mathrm{L}$ Laemmli buffer, sonicated, and denaturated at $95{ }^{\circ} \mathrm{C}$ for $5 \mathrm{~min}$. The samples were tested for equal amount of protein by Coomassie and Ponceau dye staining as well as by immunolabeling the membranes with $\beta$-Actin to confirm equal protein loading in each lane. The samples were loaded in the gel $(20 \mu \mathrm{L})$, separated by electrophoresis on $8 \%$ SDS-polyacrylamide gels (SDS-PAGE), and electrophoretically transferred to a nitrocellulose membrane. After blocking with $5 \%$ milk in PBST for $2 \mathrm{~h}$ at room temperature, membranes were incubated with the antibodies directed against the phosphorylated form of histone $\mathrm{H} 2 \mathrm{AX}$ for $1 \mathrm{~h}$ at $37^{\circ} \mathrm{C}$. Membranes were washed with PBST and further incubated with horseradish peroxidase-conjugated secondary antibodies, for $1 \mathrm{~h}$ at $37^{\circ} \mathrm{C}$. Membranes were reacted with the ECF detection system and were exposed to Kodak X-Ray film. 
Fiuza et al.

\section{Results}

\section{Simple proliferation assays}

\section{Continuous exposure experiments}

To accomplish the proposed objectives, several experiments were performed, starting with the investigation of the simple antiproliferative profile of the $\mathrm{Pd}_{2}-\mathrm{Spm}$ complex. SRB assays indicate that $\mathrm{Pd}_{2}-$ Spm inhibits MDA-MB-231 proliferation more strongly than MCF-7 cells (Figure 2, Table 1). Indeed, MCF-7 cells are able to recover from the effect of $\mathrm{Pd}_{2}-\mathrm{Spm}$ at 2 and $4 \mu \mathrm{M}$. Although the $\mathrm{Pd}_{2}-\mathrm{Spm}$ complex is not very effective at lower concentrations $(2 \mu \mathrm{M}$ for MDA-MB-231 and 2 and $4 \mu \mathrm{M}$ for MCF-7), for the maximum dosage tested $(8 \mu \mathrm{M})$, it has a dramatic effect within $24 \mathrm{~h}$. In contrast to $\mathrm{Pd}_{2}-\mathrm{Spm}$, cisplatin more effectively inhibits the proliferation of MCF-7 than MDA-MB-231 cells (but requires more than 3 days of treatment to do so). In fact, for the latter, at $96 \mathrm{~h}$ of incubation, the effect of $8 \mu \mathrm{M}$ of $\mathrm{Pd}_{2}-\mathrm{Spm}$ is only reproduced using twice the dose of $\mathrm{CDDP}(16 \mu \mathrm{M})$. Nevertheless, cDDP is more effective than $\mathrm{Pd}_{2}$-Spm at $2 \mu \mathrm{M}$ for the MDA-MB-231 cell line and 2 and $4 \mu \mathrm{M}$ for the MCF-7 cell line after four population doublings. Regarding the MCF-7 line, cDDP's maximum activity is only verified after an incubation time of $168 \mathrm{~h}$ (about four population doublings) which is reflected in its $\mathrm{IC}_{50}$ values (Table $1-24$ versus $72 \mathrm{~h}$ for both cell lines). Overall, cDDP presented a certain lag time relative to $\mathrm{Pd}_{2}$ Spm for both cell lines, corresponding to a quite low growth inhibition profile for the early first time-point (24 h).

\section{Survival of BJ fibroblasts as a non-tumorigenic model}

To examine how $\mathrm{Pd}_{2} \mathrm{Spm}$ compared with cDDP in targeting nonmalignant cells, the effects of these compounds were tested on normal (untransformed) fibroblasts. Both compounds behave very similarly (Figure 2), and for the lowest concentrations used (2 and $4 \mu \mathrm{M})$, BJ cell survival is never lower than $80 \%$, with higher
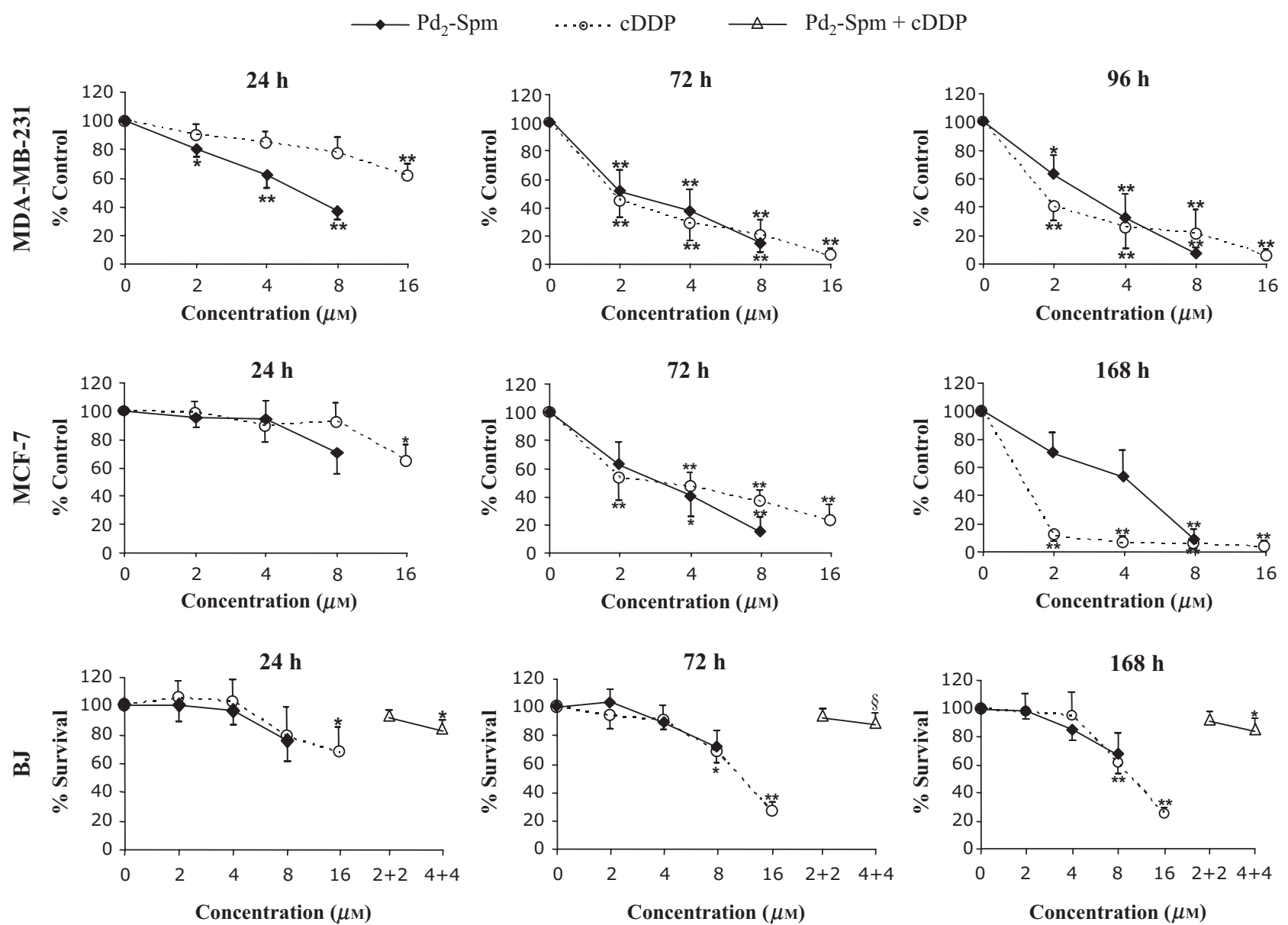

Figure 2: Continuous exposure experiment proliferation results for the MDA-MB-231, MCF-7, and BJ cell lines exposed to Pd2-Spm and CDDP. The results are presented as percentage of the control \pm SEM and are compared for equal time periods (24 and $72 \mathrm{~h})$ and in terms of population doublings (about four population doublings at $96 \mathrm{~h}$ for MDA-MB-231 and at $168 \mathrm{~h}$ for MCF-7 cell line; BJ cell line takes about $167 \mathrm{~h}$ to duplicate, and therefore, the results reflect only one population doubling are only presented as a percentage of survival instead of proliferation). The one-way ANOVA statistical analysis was used, and the Neuman-keuls post-test was carried out to verify the significance of the obtained results ( ${ }^{* *} p<0.001 ;{ }^{*} p<0.01 ;{ }^{\S} p<0.05$ versus control for the same time-point). 
Biologic Activity of a Dinuclear Pd(II)-Spermine Complex

Table 1: Calculated $I C_{50}$ values for the different experiments presently performed. For the proliferation assays of $\mathrm{Pd}_{2}-\mathrm{Spm}$ combined with cDDP, a synergy parameter (eqn 1) is also included

\begin{tabular}{|c|c|c|c|c|}
\hline \multirow[b]{3}{*}{ Experiment } & \multicolumn{4}{|c|}{$\mathrm{IC}_{50}$} \\
\hline & \multicolumn{2}{|c|}{ MCF-7 } & \multicolumn{2}{|c|}{ MDA-MB-231 } \\
\hline & $24 \mathrm{~h}$ & $72 \mathrm{~h}$ & $24 \mathrm{~h}$ & $72 \mathrm{~h}$ \\
\hline \multirow[t]{4}{*}{ Simple proliferation assays } & \multicolumn{4}{|c|}{$\mathrm{Pd}_{2}-\operatorname{Spm}(\mu \mathrm{M})$} \\
\hline & 10.9 & 3.3 & 4.7 & 2.8 \\
\hline & \multicolumn{4}{|c|}{$\operatorname{cDDP}(\mu \mathrm{M})$} \\
\hline & 22.3 & 2.8 & 20.2 & 3.2 \\
\hline & & & \multicolumn{2}{|c|}{ MDA-MB-231 } \\
\hline \multirow{5}{*}{$\begin{array}{l}\text { Proliferation assays in the } \\
\text { presence of wortmannin }\end{array}$} & & & \multirow{2}{*}{\multicolumn{2}{|c|}{$\begin{array}{c}24 \mathrm{~h} \\
\mathrm{Pd}_{2}-\operatorname{Spm}(\mu \mathrm{M})\end{array}$}} \\
\hline & & & & \\
\hline & & & 5.2 & \\
\hline & & & \multicolumn{2}{|c|}{$\operatorname{cDDP}(\mu \mathrm{M})$} \\
\hline & & & 37.2 & 8.0 \\
\hline \multirow[t]{2}{*}{$\begin{array}{l}\text { Proliferation assays of } \mathrm{Pd}_{2}-\mathrm{Spm} \\
\text { combined with cDDP. Schedule (i) }\end{array}$} & & & \multicolumn{2}{|c|}{$\begin{array}{c}\mathrm{Pd}_{2}-\mathrm{Spm}+\mathrm{cDDP} \\
(\mu \mathrm{M})\end{array}$} \\
\hline & & & & 1.1 \\
\hline \multirow{2}{*}{\multicolumn{2}{|c|}{$\begin{array}{l}\text { Proliferation assays of } \mathrm{Pd}_{2}-\mathrm{Spm} \\
\text { combined with cDDP. Schedule (ii) }\end{array}$}} & & \multicolumn{2}{|c|}{$\operatorname{cDDP}(\mu \mathrm{M})$} \\
\hline & & & 0.83 & 0.66 \\
\hline $\begin{array}{l}\text { Proliferation assays of } \mathrm{Pd}_{2}-\mathrm{Spm} \\
\text { combined with cDDP }\end{array}$ & & $l^{\mathrm{a}}$ & & vation \\
\hline $2 \mu \mathrm{M} \mathrm{Pd}_{2}-\mathrm{Spm}+2 \mu \mathrm{M} \mathrm{cDDP}$ & & 0.6 & & \\
\hline $4 \mu \mathrm{M} \mathrm{Pd}{ }_{2}-S p m+4 \mu \mathrm{M} \mathrm{cDDP}$ & & 0.9 & & \\
\hline
\end{tabular}

${ }^{\mathrm{a}}$ For details, refer to Experimental Section (Proliferation assays - Proliferation assays of $\mathrm{Pd}_{2}-\mathrm{Spm}$ combined with $\left.\mathrm{cDDP}\right)$.

dosages leading to a lower survival rate. In general, BJ cells appear to be more resistant to both $\mathrm{Pd}_{2}-\mathrm{Spm}$ and cDDP than MDAMB-231 and MCF-7. These results are important, because they provide promising data for the selectivity of the $\mathrm{Pd}_{2}-\mathrm{Spm}$ complex.

\section{Simple proliferation assays}

\section{Non-continuous exposure experiments}

To determine the irreversibility of the antiproliferative effect of the compounds under study, experiments were also performed in a non-continuous manner, by removing the culture medium after continuous exposure to the drug for a period equal to one population doubling time (26 h for MDA-MB-231 and 51 h for MCF-7).

In general, the data for this non-continuous treatment evidence lower cell density values than the ones observed for the continuous treatment (Figure 3), with most of the variations lying within the experimental error range. This is possibly due, at least partially, to the experimental protocol, because the removal of the culture media followed by the extra washing step may dislodge and remove some cells, especially those that are dividing (which are rounded up and weakly attached). The main conclusion to withdraw from this experiment is that the damage induced by these compounds occurs mainly at the first population doublings and that it is not reversible for the experimental conditions tested.

In sum, the simple proliferation experiments allowed to conclude for the tested cell lines that: (i) $\mathrm{Pd}_{2}-\mathrm{Spm}$ is more active than cDDP in rapidly suppressing the ER(-) MDA-MB-231 cell line growth; (ii) $\mathrm{Pd}_{2}-\mathrm{Spm}$ is less active than cDDP in long-term suppression of MCF-7 cells; (iii) compared to cisplatin, $\mathrm{Pd}_{2}-\mathrm{Spm}$ is more effective at early time-points; (iv) the responses of the normal fibroblast cell line were similar to both $\mathrm{Pd}_{2}-\mathrm{Spm}$ and cDDP and (v) overall, both of these malignant cell lines appeared to be more sensitive to both compounds than normal BJ fibroblasts, especially for longer time periods and higher doses of the compounds.

To certify that the verified antiproliferative effect was because of the complex as a whole as well as to aid the SAR's (StructureActivity Relationships) investigation, the $\mathrm{Pd}(\mathrm{II})$ complex was considered as the sum of different chemical entities that could, by themselves, be significant for the overall biologic activity of the compound. For this reason, the spermine ligand (Figure 1D) was studied at equivalent concentrations of the complex (one spermine molecule per one complex unit), and the smaller palladium complex $\mathrm{Pd}(\mathrm{dap}) \mathrm{Cl}_{2}$ (which is a good model of the metal co-ordination environment in $\mathrm{Pd}_{2}-\mathrm{Spm}$; Figure $1 \mathrm{C}$ ) was screened as to its antiproliferative profile using twice the concentration of $\mathrm{Pd}_{2}-\mathrm{Spm}$ to attain an equivalent number of metals centers. It was verified that neither spermine nor $\mathrm{Pd}(\mathrm{dap}) \mathrm{Cl}_{2}$ displayed any antiproliferative effect against the cell lines studied and for the concentrations tested (data not shown) and were therefore not considered on further experiments.

Because one of the goals of this study is to assess the possible targets of $\mathrm{Pd}_{2}-\mathrm{Spm}$, the following experiments were only performed for the MDA-MB-231 cell line, which was found to be more sensitive to this compound.

\section{DNA damage $-\gamma H 2 A X$ quantification by Western blot analysis}

DNA damage can be divided in two general classes: single-base alterations and structural distortions. Cisplatin damages DNA by structural distortion through the formation of bulky adducts that result from covalent binding to the bases. These distortions are mainly because of intrastrand cross-links with the double helix $(\sim 90 \%)$ with only a small portion of the lesions being because of monoadducts and about $2 \%$ as a result of interstrand cross-links (ICLs) (30). These lesions block replication and transcription and might cause replication-mediated double-strand breaks (DSBs) (31). As cDDP, metal-based drugs such as Pd(II) and Pt(II) complexes are expected to interact with DNA $(32,33)$. Because $\mathrm{Pd}_{2}-\mathrm{Spm}$ presented good antiproliferative results, the next step was to assess whether $\mathrm{Pd}_{2}$-Spm damages DNA, specifically by the induction of DSBs that are considered to be the most damaging biologic lesion that can take place in the cell (34).

The results obtained are depicted in Figure 4 and show that $\mathrm{Pd}_{2}$ Spm induces H2AX phosphorylation to a high extent, evidencing a 


\section{Fiuza et al.}

$48 \mathrm{~h}$
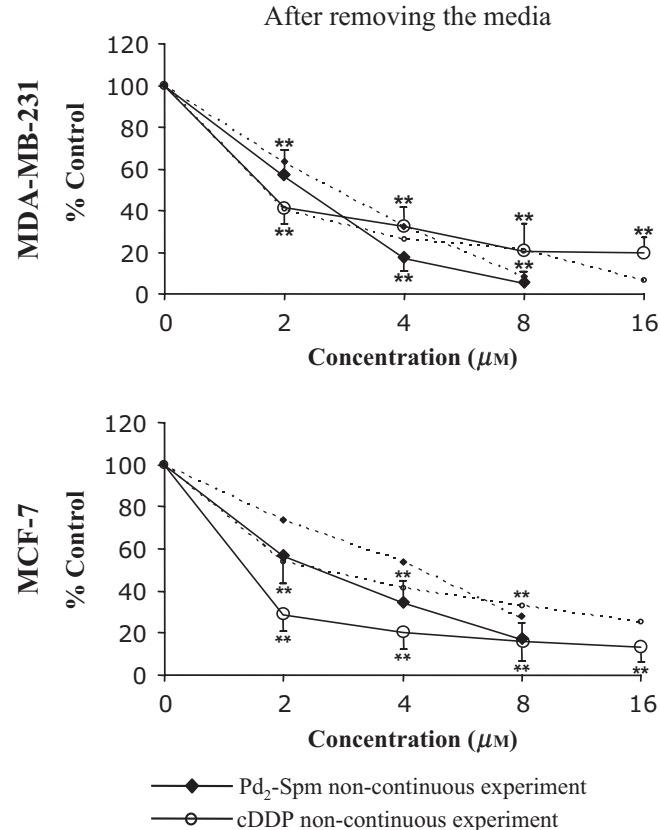

3 population doublings

After removing the media
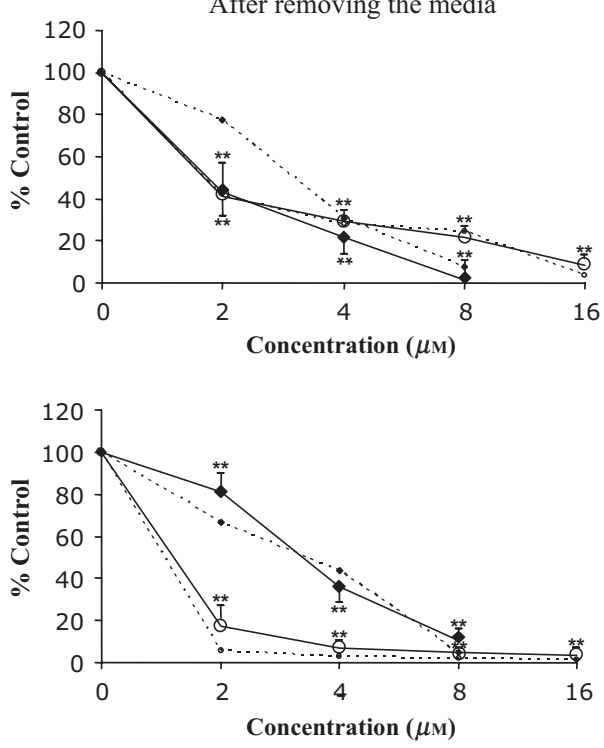

..... $\mathrm{Pd}_{2}-\mathrm{Spm}$ values for the continuous experiment . . - ० - . cDDP values for the continuous experiment

Figure 3: Non-continuous exposure experiment for MDA-MB-231 and MCF-7 cell lines. The results are presented as percentage of the control \pm SEM. After the initial exposure to either $\mathrm{Pd}_{2}-\mathrm{Spm}$ or $\mathrm{CDDP}$ during one population doubling $(26 \mathrm{~h}$ for MDA-MB-231 and $51 \mathrm{~h}$ for MCF-7), the media containing the drug was removed, the cells were washed with PBS, and fresh media was added to the cells. The cells were collected $48 \mathrm{~h}$ and three population doublings after this procedure. Data obtained for equivalent time-points were collected from Figure 2 (Continuous exposure treatment) for comparison purposes and are presented as dashed lines. The error bars of this experiment are not presented for simplicity purposes. The one-way ANovA statistical analysis was used, and the Neuman-keuls post-test was carried out to verify the significance of the obtained results $\left(^{* *} p<0.001\right.$ versus control for the same time-point).

damaging interaction with DNA. This damage occurs relatively rapidly (within $6 \mathrm{~h}$ of drug administration), and the effect is higher for $\mathrm{Pd}_{2}$-Spm than for cDDP. The early time-point and the lack of morphological features of apoptosis exclude the possibility of apoptosis-induced H2AX phosphorylation. The increased levels of DNA damage (implied by $\mathrm{H} 2 \mathrm{AX}$ phosphorylation) induced by $\mathrm{Pd}_{2}-\mathrm{Spm}$ could explain the significantly greater inhibition of proliferation measured for this compound when compared to cDDP at the 24-h time-point. However, further experiments are needed to establish a relation between DNA damage and cell growth inhibition.

\section{DNA-PK-mediated DNA repair - proliferation assays in the presence of Wortmannin}

In light of the results yielded by the H2AX experiment, proliferation assays were performed in the presence of the phosphoinositide 3kinases (PI3K's) (35) inhibitor wortmannin, which suppresses H2AX phosphorylation (36) and DNA and DSB repair. DNA repair is known to be one of the causes of resistance displayed by cancer cells to the effect of DNA-damaging antineoplastic drugs. The fungal furanosteroid metabolite wortmannin was shown to inhibit DSBs repair processes and can therefore potentiate the DNA-damaging effect of anticancer drugs $(29,37,38)$.

There are five recognized DNA repair pathways: nucleotide excision repair (NER), mismatch repair (MMR), double-strand break repair

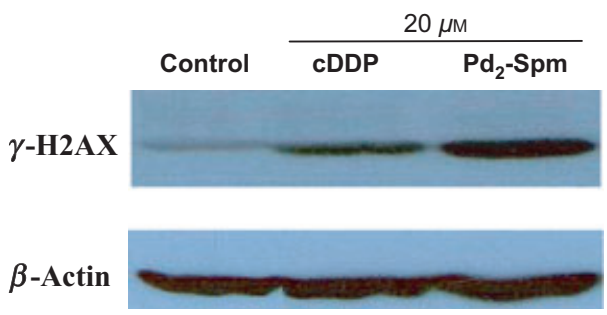

Figure 4: Western blot detection of $\mathrm{H} 2 \mathrm{AX}$ phosphorylation $(\gamma \mathrm{H} 2 \mathrm{AX})$ for the MDA-MB-231 cell line. Cells were exposed for $6 \mathrm{~h}$ to $20 \mu \mathrm{M}$ of each $\mathrm{Pd}_{2}-\mathrm{Spm}$ and $\mathrm{CDDP}$ with the same amount of vehicle solution (PBS) added to the control cells. The cells were collected and processed as described in the Experimental Section. The $\beta$-Actin immunolabeling is presented to verify the equal amount of protein.

(DSBr), base excision repair (BER), and direct repair (DR). Two general types of mechanisms exist for DSB repair: homologous recombination (HR) and non-homologous end-joining (NHEJ) with the latter been described as the predominant DSB repair mechanism in mammalian cells (39-41). NER and MMR appear to be major repair pathways of cisplatin-induced DNA damage (42), with the NHEJ pathway being activated for DSB repair in cisplatin-treated cells $(39,43)$. The NHEJ pathway that involves the DNA-PK holoenzyme 
Biologic Activity of a Dinuclear Pd(II)-Spermine Complex

$(44,45)$ is greatly inhibited by Wortamnnin $(27,29,37)$ by interaction with DNA-PKcs subunits that belong to the PI3K family.

Considering that $\mathrm{Pd}_{2}-\mathrm{Spm}$ induces DSBs in DNA, we wanted to test whether the proliferation of MDA-MB-231 cells in the presence of $\mathrm{Pd}_{2}$-Spm was affected if this DSB repair pathway was inhibited. An enhancement of the growth inhibition effect was previously detected in the presence of wortmannin for etoposide and alkylating agents such as chlorambucil $(29,37)$, which induce different adducts with DNA (including ICLs), as well as for ionizing radiation also known to cause DSBs (38).

Proliferation assays in the presence of wortmannin were performed toward the MDA-MB-231 cell line, exposing both the control and the test cells to $10 \mu \mathrm{M}$ of wortmannin for $1 \mathrm{~h}$ prior to drug administration as described in the experimental section.

The results obtained, depicted in Figure 5, evidence that wortmannin hardly affects the antiproliferative profile of $\mathrm{Pd}_{2}-\mathrm{Spm}$ evidencing that DSB repair does not appear to play a key role in $\mathrm{Pd}_{2}$ Spm mechanism of action. In fact, most alterations are within the experimental error range, and only a greater enhancement effect is verified for $2 \mu \mathrm{M}$ of $\mathrm{Pd}_{2}$-Spm at the 96-h time-point. It is interesting to notice that this improvement is occurring for the lowest concentration of $\mathrm{Pd}_{2}-\mathrm{Spm}$, which is the only dosage for which recovery is verified on the simple proliferation assays (Figure 2, for the MDA-MB-231 cell line in the presence of $2 \mu \mathrm{M}$ of $\mathrm{Pd}_{2}-\mathrm{Spm}$ at $72 \mathrm{~h}$ versus $2 \mu \mathrm{m}$ at $96 \mathrm{~h}$ ). This may suggest that the cell recovery observed is at least in some part because of DNA repair. The fact that this type of DNA repair is not related to the high amount of DSBs induced, can be as a result of different reasons one of them being that for higher dosages of $\mathrm{Pd}_{2}-\mathrm{Spm}(4$ and $8 \mu \mathrm{M}$ in this case), the cell DNA repair capacity might be insufficient to maintain, and it does not become significant to inhibit DNA repair under these conditions. In fact, at higher concentrations, the compound might start targeting other components of the cell important for viability. To further evaluate the importance of DNA repair, other studies could be performed such as checking for more evident effects of wortmannin with lower doses of $\mathrm{Pd}_{2}$-Spm and testing the effects of $\mathrm{Pd}_{2}$-Spm on cell lines with known differences in their ability to repair DNA.

Cisplatin's antiproliferative effect that was measured to compare with $\mathrm{Pd}_{2}-\mathrm{Spm}$ was surprisingly found to drastically decrease in the presence of Wortmaninn (Figure 5 and Table 1). This is in accordance with a previous study performed with fibroblasts and colon carcinoma cells (HT-29) which were protected against the cytotoxic effect of cisplatin in the presence of this inhibitor (46). This may be because of an alternative and efficient repair route (47) adopted by these cells which results in an adaptative and more efficient response to cisplatin $(48,49)$, leading to a high cell survival rate in the presence of cDDP but not $\mathrm{Pd}_{2}-\mathrm{Spm}$. It should however be taken into account that wortmannin is a PI3K inhibitor with a broad spectrum of activity and can have a large effect on a variety of different cellular mechanisms, including the DNA damage-sensing Fanconi anemia/BRCA pathway that is sensitive to cross-linking agents (5052). However, Jensen and Glazer (53) using mouse fibroblasts specifically mutant on DNA-PK subunits $\left(\mathrm{Ku}^{-1-} 0^{-/}\right.$and DNA-PK $\left.{ }_{\mathrm{cs}}\right)$
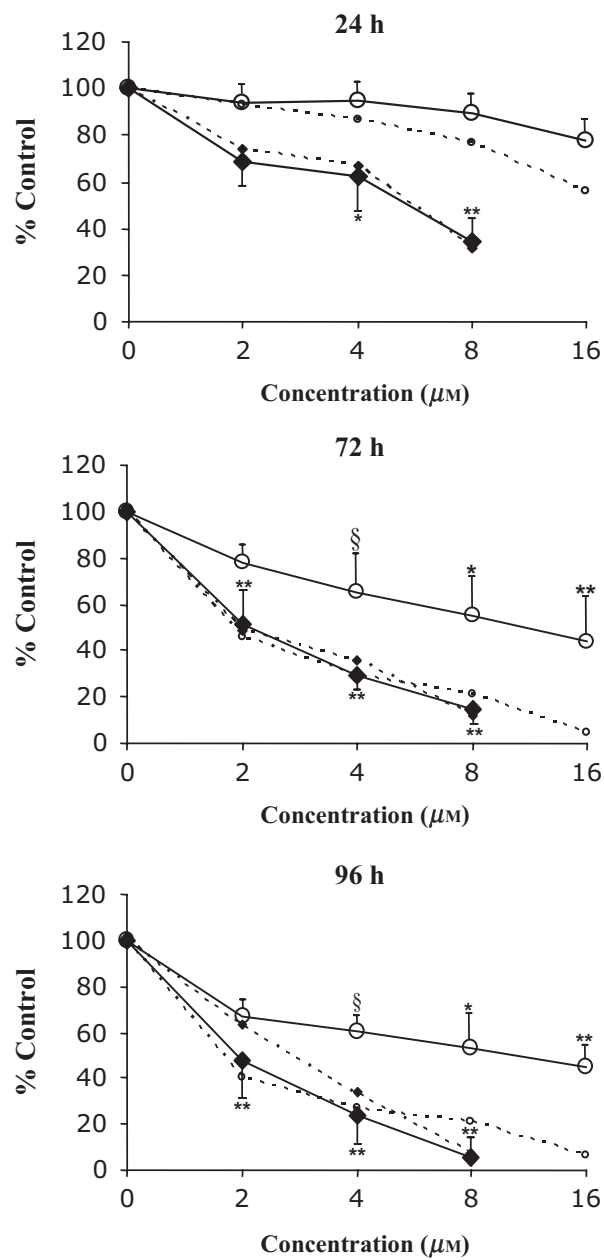

$-\mathrm{Pd}_{2}-\mathrm{Spm}$ in the presence of wortmannin
$\ldots \ldots \mathrm{Cd}_{2}-\mathrm{Spm}$ in the presence of wortmannin for the simple proliferation assay
$\ldots \ldots$.

Figure 5: Proliferations assays toward MDA-MB-231 cell line in the presence of wortmannin. The results are presented as percentage of the control \pm SEM. After the initial exposure of the control and test cells to $10 \mu \mathrm{M}$ of wortmannin for an hour, $\operatorname{Pd}_{2}-\operatorname{Spm}(2,4$, and $8 \mu \mathrm{M})$ and $\operatorname{cDDP}(2,4,8$ and $16 \mu \mathrm{M})$ were added to the test wells. The cells were collected at 24-, 72-, and 96-h time-points. Data obtained for equivalent time-points were collected from Figure 2 (Continuous exposure treatment) and presented for comparison purposes and are presented as dashed lines. The error bars of this experiment are not presented for simplicity purposes. The oneway ANOVA statistical analysis was used, and the Neuman-keuls post-test was carried out to verify the significance of the obtained results $\left({ }^{* *} p<0.001 ;{ }^{*} p<0.01 ;{ }^{\S} p<0.05\right.$ versus control for the same time-point).

showed that DNA-PK-mediated DNA repair is, in fact, important for cisplatin's mode of action.

Obviously, the mechanisms of DNA repair and cellular response are a result of intricate processes based on a multifactor balance strongly dependent on the type of cell line. The final outcome of 


\section{Fiuza et al.}

the cell is a result of a cross talk between different signal transduction pathways. Although the use of wortmannin when using proliferation assays is not the best tool to asses DNA repair unambiguously, the experiments are interesting as they constitute evidence of a different behavior of $\mathrm{Pd}_{2}$-Spm relative to CDDP. Therefore, whichever the route involved in the different behavior of CDDP and $\mathrm{Pd}_{2}-\mathrm{Spm}$ in the presence of wortmannin, the data presently gathered suggest that there might be a significant mechanistic difference between these compounds as verified for other Pt(II) versus $\mathrm{Pd}(\mathrm{II})$ systems (54).

We hypothesized that this divergence could be because of the ability of $\mathrm{Pd}_{2}-\mathrm{Spm}$ to induce DNA ICLs to a higher extent than cDDP ( 2\%) (30). ICLs are more difficult to repair than intrastrand ones, and cells seem to use several repair pathways in a co-ordinate manner to eliminate them, with different tumor types differing widely in their ICLs repair mode (55). This hypothesis, however, remains to be further verified because the experiments performed for evaluating the formation of ICLs (56) by $\mathrm{Pd}_{2}-S p m$ were not conclusive (data not shown).

At this point, it was possible to conclude that: (i) $\mathrm{Pd}_{2}-\mathrm{Spm}$ leads to DNA DSBs; (ii) $\mathrm{Pd}_{2}$-Spm induces DSBs to a higher extent than cDDP; (iii) the inhibition of DSB repair does not seem to play a key role in $\mathrm{Pd}_{2}$-Spm mechanism of action; (iv) wortmannin experiments suggest that $\mathrm{Pd}_{2}-\mathrm{Spm}$ and cDDP have a different mechanism of action.

\section{Proliferation assays of $\mathrm{Pd}_{2}-\mathrm{Spm}$ combined with cDDP}

Considering the apparent mechanistic difference between $\mathrm{Pd}_{2}-\mathrm{Spm}$ and CDDP, it was questioned if their combined effect would lead to improved efficacy. The investigation of their combined effect was assessed in two different ways: (i) by drugging the cells simultaneously with equal amounts of $\mathrm{Pd}_{2}-\mathrm{Spm}$ and $\operatorname{cDDP}(2$ and $4 \mu \mathrm{M}$ of each) using drug concentrations that were not too harmful for the fibroblasts at the single-agent experiment (Figure 2) and (ii) by administering the compounds in an alternate schedule, with an ini- tial higher dose of $\mathrm{Pd}_{2}-\mathrm{Spm}(4 \mu \mathrm{M})$ having been given at the beginning of the experiment before dropping to lower maintenance doses of cDDP (1 and $2 \mu \mathrm{M})$. This experiment was designed to profit from the key advantages of each compound $-\mathrm{Pd}_{2}-\mathrm{Spm}$ is more effective at early time-points and cDDP for longer ones.

The results obtained for the combined experiment (i) (Figure 6A) evidence that the coadministration of the test compounds yields better results than the single-agent experiments (Figure 2 versus Figure 6). In fact, the antiproliferative profile obtained in the former is more similar to the ones obtained for the higher doses tested individually (8 and $16 \mu \mathrm{M}$ of $\mathrm{Pd}_{2}-$ Spm and cDDP, respectively) with the advantage of keeping BJ survival above $80 \%$ (Figure 2).

In view of better analyzing the data obtained by this simultaneous coadministration of $\mathrm{cDDP}$ and $\mathrm{Pd}_{2}-\mathrm{Spm}$, an interaction parameter was calculated, and the results are presented in Table 1. These are indicative of a synergistic effect between both compounds, rather than an additive one for this particular assay, reinforcing the idea that these compounds display at least some differences in their mechanism of action. The type of synergistic interaction, either anticounteractive, complementary or facilitating, is however unknown (57).

The second combined experiment with alternate drugging schemes yielded a good antiproliferative profile as well (Figure 6B). After $96 \mathrm{~h}$ of $\mathrm{Pd}_{2}-\mathrm{Spm} \cdot \mathrm{cDDP}(2 \mu \mathrm{M})$ exposure, the obtained antiproliferative profile is similar to the ones of 8 and $16 \mu \mathrm{M}$ of $\mathrm{Pd}_{2}-\mathrm{Spm}$ and $\mathrm{cDDP}$, respectively, for the single-agent experiments. Nevertheless, the toxicity toward $\mathrm{BJ}$ cell line is much lower $\left(8 \mu \mathrm{M}\right.$ of $\mathrm{Pd}_{2}-\mathrm{Spm}$ and $16 \mu \mathrm{M}$ of cDDP versus $2 \mu \mathrm{M}$ of CDDP, $4 \mu \mathrm{M}$ of $\mathrm{Pd}_{2}-\mathrm{Spm}$ or even $4 \mu \mathrm{M} \mathrm{cDDP}+4 \mu \mathrm{M} \mathrm{Pd}_{2}-\mathrm{Spm}$ - Figure 2). When comparing these results with the antiproliferative profile of $4 \mu \mathrm{M}$ of $\mathrm{Pd}_{2}-S p m$ for the non-continuous experiments, it can be seen that the antiproliferative profile of the maintenance dose of $1 \mu \mathrm{M} \mathrm{cDDP}$ is slightly better than the one observed for the $4 \mu \mathrm{M}$ of $\mathrm{Pd}_{2}$-Spm and when using $2 \mu \mathrm{M}$ of cDDP, there is an accentuated effect and a greater improvement of the antiproliferative profile.
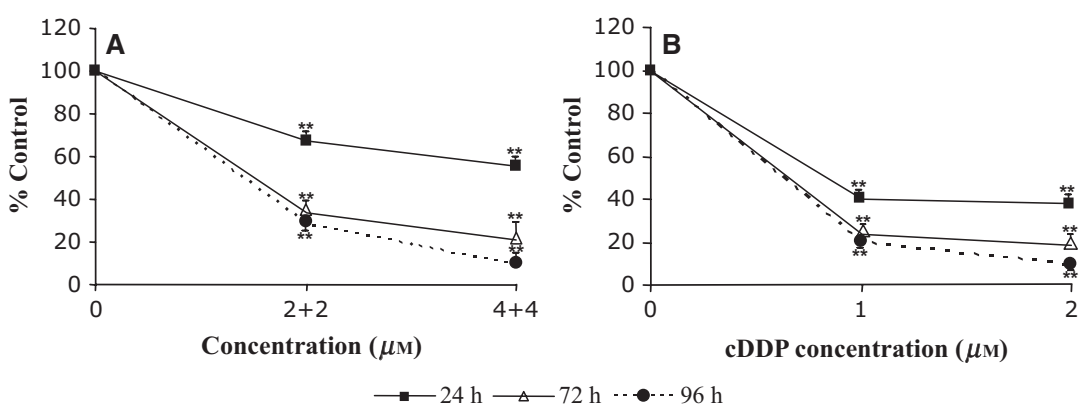

Figure 6: Proliferation assays of combined $\mathrm{Pd}_{2}-\mathrm{Spm}$ and cDDP administration toward MDA-MB-231 cell line. The results are presented as percentage of the control \pm SEM. (A) $\mathrm{Pd}_{2}$-Spm and cDDP were coadministrated with 2 and $4 \mu \mathrm{M}$ of each for 24-, 72-, and 96-h time-points. (B) Combined experiment of $\mathrm{Pd}_{2}-\mathrm{Spm}$ and cDDP with an alternate drugging scheme. Cells were exposed for $24 \mathrm{~h}$ to $4 \mu \mathrm{M}$ of $\mathrm{Pd} \mathrm{d}_{2}-\mathrm{Spm}$. After this time-point, the media was removed and the cells were washed with PBS. Fresh media was added to the cells, and a maintenance dose (1 or $2 \mu \mathrm{M}$ ) of CDDP was administrated to the cells. Incubation times of 24-, 72-, and 96-h counting after the addition of cDDP were considered. The one-way ANOVA statistical analysis was used, and the Neuman-keuls post-test was carried out to verify the significance of the obtained results $\left({ }^{* *} p<0.001 ;{ }^{*} p<0.01\right.$ versus control for the same time-point). 


\section{Biologic Activity of a Dinuclear Pd(II)-Spermine Complex}

Any of these combined schemes seem to be a good alternative to the use of higher dosages of the compounds used individually at a low toxicity cost and benefiting from both their intrinsic advantages.

An individual experiment has not been performed simultaneously for the BJ cell line because the individual toxicity found for the maximum doses used in this experiment was considered to be rather low (4 $\mu \mathrm{M}$ of $\mathrm{Pd}_{2}-$ Spm with BJ survival above $80 \%$ and $2 \mu \mathrm{M}$ cDDP yielded BJ survival values above $90 \%$; Figure 2). It was also observed that the combined use of CDDP and $\mathrm{Pd}_{2}-\mathrm{Spm}$ at $4 \mu \mathrm{M}+4 \mu \mathrm{M}$ also allowed a BJ survival above $80 \%$ (Figure 6).

The combined experiments allowed to shown that: (i) $\mathrm{Pd}_{2}$-Spm acts synergistically with cDDP; (ii) a staggered or combined drugging scheme can improve both compounds efficacy; (iii) this data reinforce the idea of a different mechanism of action of these compounds.

\section{Pd $_{2}$-Spm effects on the cytoskeleton - immunocytochemistry}

In addition to damaging DNA, cDDP has been shown to alter other aspects of cell function, including the organization of the cytoskeleton. Previous studies show that cisplatin arrests tubulin polymerization (58), induces MCF-7 cytoskeleton remodeling (59), and interferes with microtubule and intermediate filament organization
(60). To compare $\mathrm{Pd}_{2} \mathrm{Spm}$ and cDDP effects on cytoskeleton, microfilaments and microtubules were labeled in control and drug-treated MDA-MB-231 cells. Both compounds exhibited stronger effects on microtubules than on microfilaments (Figure $7 \mathrm{C}$ versus D). While 2 and $4 \mu \mathrm{M}$ of cDDP seem to have a similar effects on microtubule organization, $\mathrm{Pd}_{2}-\mathrm{Spm}$ is more damaging, and there is a greater effect for $4 \mu \mathrm{M}$ relative to $2 \mu \mathrm{M}$. At higher $\mathrm{Pd}_{2}-$ Spm concentrations, the microfilaments also begin to look somewhat affected. Either this is a primary target for the $\mathrm{Pd}(\mathrm{II})$ complex or not remains under investigation.

\section{Conclusions}

A dinuclear palladium-based complex, $\mathrm{Pd}_{2}-\mathrm{Spm}$, was synthesized and compared with cisplatin on two different human breast cancer cell lines, MCF-7 and MDA-MB-231, as well as a normal, untransformed cell line (BJ fibroblasts). The results obtained show that both $\mathrm{Pd}_{2}-\mathrm{Spm}$ and $\mathrm{CDDP}$ have good antiproliferative profiles against the human breast cancer cell lines tested. However, compared to cDDP, $\mathrm{Pd}_{2}-\mathrm{Spm}$ is more effective against the $\mathrm{ER}(-)$ cell line MDAMB-231, but less effective against the ER(+) MCF-7 cell line. Despite the fact that the results for CDDP against MCF-7 are very good, MCF-7 is ER(+) and this type of cancer has a diversity of possible compounds for treatment, namely estrogen antagonists. This raises the possibility that $\mathrm{Pd}_{2}-\mathrm{Spm}$ could be of greater use than cDDP against more advanced, ER(-) breast cancers. It was shown

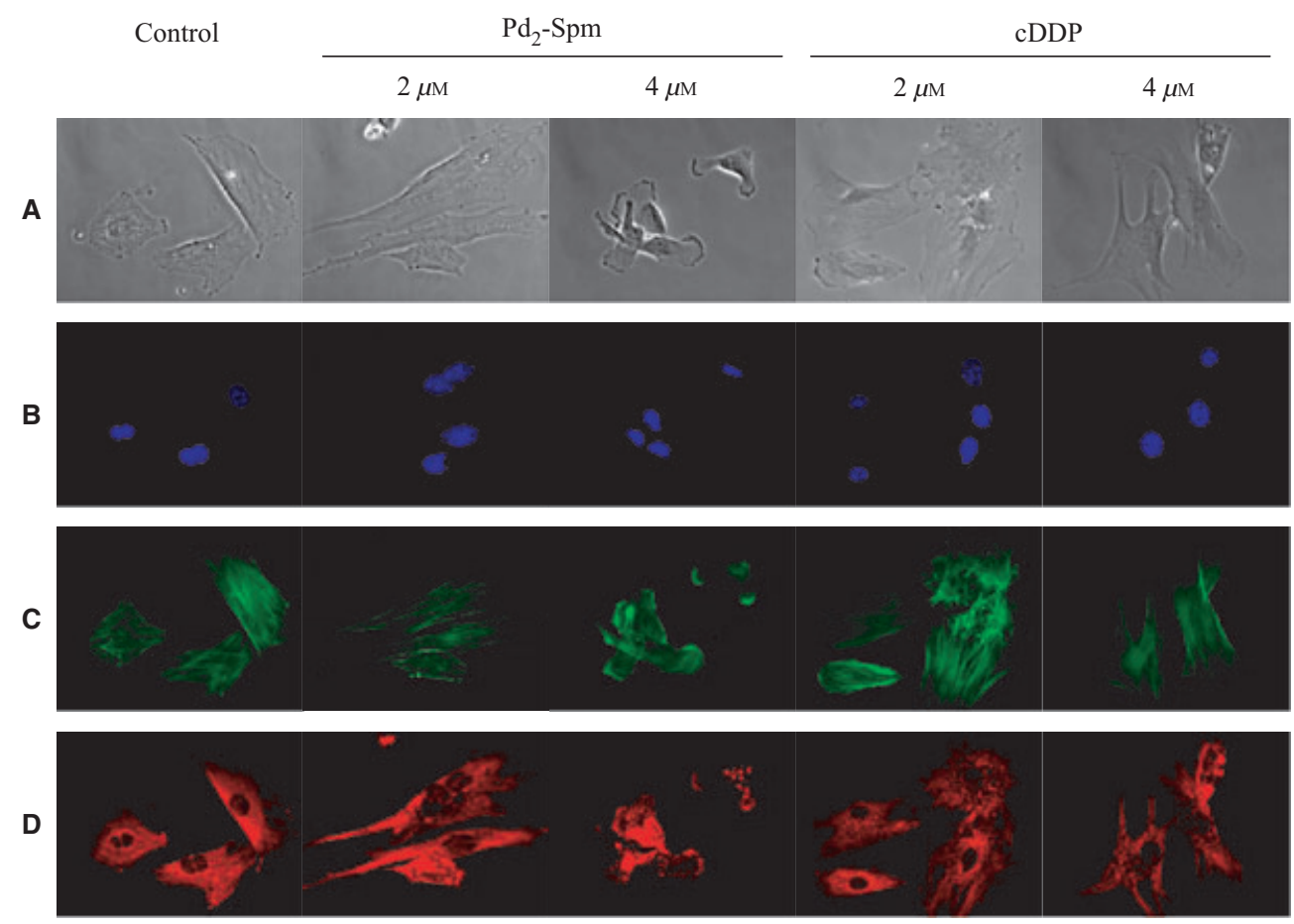

Figure 7: Immunocytochemistry results for the MDA-MB-231 cell line with labeled microtubules and microfilaments. Cells were grown in glass coverslips and exposed to 2 and $4 \mu \mathrm{M}$ of either $\mathrm{Pd}_{2}$-Spm or cDDP for $24 \mathrm{~h}$ and then collected and fixed in the appropriate solution. The monoclonal anti- $\beta$-tubulin antibody E7 was used to label micotubules, DNA was fluorescently stained with $5 \mu \mathrm{g} / \mathrm{mL} \mathrm{Hoechst} 33258$, and the microfilaments (F-actin) were labeled with rhodamine-conjugated phalloidin. Coverslips were mounted in antifade medium to retard photobleaching and examined and photographed with a Nikon Eclipse 3000 epifluorescence microscope. (A) Phase contrast; (B) Hoescht labeling; (C) Phalloidin labeling; (D) $\beta$-tubulin labeling. 


\section{Fiuza et al.}

that, like $\mathrm{CDDP}, \mathrm{Pd}_{2}-\mathrm{Spm}$ triggers phosphorylation of $\mathrm{H} 2 \mathrm{AX}$, indicating that this compound damages DNA. The exact nature of the DNA lesions imparted by $\mathrm{Pd}_{2} \mathrm{Spm}$ has not been defined, but activation of $\mathrm{H} 2 \mathrm{AX}$ suggests that the damage at least includes DSBs. Although the wortmannin experiments did not determine whether there were differences in the repair of cDDP- and $\mathrm{Pd}_{2} \mathrm{Spm}$-induced DNA damage, the fact that $\mathrm{Pd}_{2}-\mathrm{Spm}$ antiproliferative activity was only slightly affected, while cDDP growth inhibition was highly antagonized seems to evidence that $\mathrm{Pd}_{2}$-Spm must have other targets in the cell and that there is a marked difference in the cellular response to these two compounds, further arguing for distinct mechanisms of action. Also, at an optimized concentration, this agent has a rapid antiproliferative effect as opposed to cDDP, which seems to display a slower kinetics.

These results point to different mechanism of action of the two complexes which may explain their synergistic action when coadministered. Apart from DNA, $\mathrm{Pd}_{2}-\mathrm{Spm}$ also targets the cytoskeleton having a greater impact on cell morphology than cDDP, because $\mathrm{Pd}_{2}$-Spm was found to disrupt the microtubules to a larger extent. Despite the emphasis on the data that evidence that $\mathrm{Pd}_{2}-\mathrm{Spm}$ and cDDP have distinct mechanistic pathways, the difference in their effectiveness appears to stem in the diverse modes of interaction on either different or shared molecular targets such as the DNA and the cytoskeleton which were presently found to be two important targets for $\mathrm{Pd}_{2}-\mathrm{Spm}$.

Furthermore, it can be concluded that the $\mathrm{Pd}_{2}-\mathrm{Spm}$ complex as a whole entity displays a considerable cell growth inhibition effect, because neither the polyamine ligand nor the analogous metal complex $\mathrm{Pd}($ dap $) \mathrm{Cl}_{2}$ was shown to have significant antiproliferative profiles. Overall, this suggests that $\mathrm{Pd}(\mathrm{II})$ compounds are interesting enough to pursue as novel anticancer agents and may be developed to increase the efficacy of cDDP-type chemotherapeutics.

\section{Acknowledgments}

The authors acknowledge financial support from the Portuguese Foundation for Science and Technology - R\&D Research Unit 'Química-Física Molecular' - University of Coimbra (Portugal), Research Projects POCTI/47256/0UI/2002 (co-financed by the European Community fund FEDER) and PTDC/QUI/66701/2006, and PhD fellowship SFRH/BD/17493/2004 (SMF). Thanks are due to the Biochemistry Service of the Faculty of Medicine of the University of Coimbra for having made available the MCF-7 cell line.

\section{References}

1. World Health Organization (2008) Mortality Profiles. Geneva: WHO.

2. Bastos J., Barros H., Lunet N. (2007) Evolução da mortalidade por cancro da mama em Portugal (1955-2002). Acta Med Port;20:139-144.

3. Rosenberg B., Van Camp L., Trosko J.E., Mansour V.H. (1969) Platinum compounds: a new class of potent antitumor agents. Nature;222:385-386.
4. Nielsen T.O., Hsu, F.D, Jensen, K., Cheang, M., Karaca, G., Hu, Z., Hernandez-Boussard, T. et al. (2004) Immunohistochemical and clinical characterization of the basal-like subtype of invasive breast carcinoma. Clin Cancer Res;10:5367-5374.

5. Galanski M., Arion V.B., Jakupec M.A., Keppler B.K. (2003) Recent developments in the field of tumor-inhibiting metal complexes. Curr Pharm Des;9:2078-2089.

6. Zeizinger M., Burda J.V., Sponer J., Kapsa V., Leszczynski J. (2001) A systematic ab initio study of the hydration of selected palladium square-planar complexes. A comparison with platinum analogues. J Phys Chem A;105:8086-8092.

7. Burda J.V., Zeizinger M., Leszczynski J. (2004) Activation barriers and rate constants for hydration of platinum and palladium square-planar complexes: an ab initio study. J Chem Phys:120:1253-1262.

8. Ray S., Mohan R., Singh J.K., Samantaray M.K., Shaikh M.M., Panda D., Ghosh P. (2007) Anticancer and Antimicrobial metallopharmaceutical agents based on palladium, gold, and silver Nheterocyclic carbene complexes. J Am Chem Soc;129:1504215053.

9. Kuduk-Jaworska J., Puszko A., Kubiak M., Pě̆lczynska M. (2004) Synthesis, structural, physico-chemical and biological properties of new palladium (II) complexes with 2,6-dimethyl-4-nitropyridine. J Inorg Biochem;98:1447-1456.

10. Mansuri-Torshizi H., Ghadimy S., Akbarzadeh N. (2001) Synthesis, characterization, DNA binding and cytotoxic studies of platinum(II) and palladium(II) complexes of the 2,2'-bipyridine and an anion of 1,1-cyclobutanedicarboxylic acid. Chem Pharmacol Bull;:49:1517-1520.

11. Fiuza S.M., Amado A.M., Oliveira P.J., Sardão V.A., Batista de Carvalho L.A.E., Marques M.P.M. (2006) Pt(II) vs Pd(II) polyamine complexes as new anticancer drugs: a structure-activity study. Lett Drug Des Discov;3:149-151.

12. Budzisz E., Krajewska U., Rozalski M. (2004) Cytotoxic and proapoptotic effects of new $\mathrm{Pd}(\mathrm{II})$ and $\mathrm{Pt}(\mathrm{II})$-complexes with 2-ethanimidoyl-2-methoxy-2H-1,2-benzoxaphosphinin-4-ol-2-oxide. Pol J Pharmacol;56:473-478.

13. Butour L., Wimmer Wimmer F., Castan P. (1997) Palladium(II) compounds with potential antitumour properties and their platinum analogues: a comparative study of the reaction of some orotic derivatives with DNA in vitro. Chem Biol Interact;104:165-178

14. Wheate N.J., Collins J.G. (2003) Multi-nuclear platinum complexes as anti-cancer drugs. Coord Chem Rev;241:133-145.

15. Teixeira L.J., Seabra M., Reis E., Girao da Cruz M.T., Pedroso de Lima M.C., Pereira E., Miranda M.A., Marques M.P.M. (2004) Cytotoxic activity of metal complexes of biogenic polyamines: polynuclear platinum(II) chelates. J Med Chem;47:2917-2925.

16. Marques M.P.M., Girao T., De Lima M.C.P., Gameiro A., Pereira E., Garcia P. (2002) Cytotoxic effects of metal complexes of biogenic polyamines. I. Platinum(II) spermidine compounds : prediction of their antitumour activity. Biochim Biophys Acta;1589:6370 .

17. Jodrell D.I., Evans T.R.J., Steward W., Cameron D., Prendiville J., Aschele C., Noberasco C., Lind M., Carmichael J., Dobbs N., Camboni G., Gatti B., De Braud F. (2004) Phase II studies of BBR3464, a novel tri-nuclear platinum complex, in patients with 


\section{Biologic Activity of a Dinuclear Pd(II)-Spermine Complex}

gastric or gastro-oesophageal adenocarcinoma. Eur $\mathrm{J}$ Cancer;40:1872-1877.

18. Ou Y., Scarsdale N.J., Tran M.-C., Farrell N. (2004) Comparison of structural effects in 1,4 DNA-DNA interstrand cross-links formed by dinuclear and trinuclear platinum complexes. J Inorg Biochem;98:1585-1590.

19. Marverti G., Andrews P.A., Piccini G., Ghiaroni S., Barbieri D., Moruzzi M.S. (1997) Modulation of cis-diamminedichloroplatinum(II) accumulation and cytotoxicity by spermine in sensitive and resistant human ovarian carcinoma cells. Eur J Cancer;33:669-675.

20. Codina G., Caubet A., López C., Moreno V., Molins E. (1999) Palladium(II) and Platinum(II) Polyamine Complexes: X-Ray Crystal Structures of (SP-4-2)-Chloro\{N-[(3-amino-kN)-propyl]propane-1,3diamine-kN,kN'\}palladium(1+)Tetrachloropalladate(2-)(2:1) and (R,S)-Tetrachloro[n-(spermine)dipalladium(II) $\left(=\left\{\mathrm{N}, \mathrm{N}^{\prime}\right.\right.$-Bis[(3-aminokN)-propyl]butane-1,4-diamine-kN:kN'\}tetrachlorodipalladium). Helv Chim Acta;82:1025-1037.

21. Gurel V., Sens D.A., Somji S., Garrett S.H., Nath J., Sens M.A. (2003) Stable transfection and overexpression of metallothionein isoform 3 inhibits the growth of MCF-7 and Hs578T cells but not that of T-47D or MDA-MB-231 cells. Breast Cancer Res Treat;80:181-191.

22. Keepers Y.P., Pizao P.E., Peters G.J., van Ark-Otte J., Winograd B., Pinedo H.M. (1991) Comparison of the sulforhodamine B protein and tetrazolium (MTT) assays for in vitro chemosensitivity testing. Eur J Cancer;27:897-900.

23. Lazic M.J., Andelkovic K.K., Sladic D.M., Tesic Z.L., Radulovic S.S. (2005) The evaluation of cytotoxic activity of planar pentadentate ligand $2^{\prime}, 2^{\prime \prime \prime}$-(2,6-pyridindiyldiethylidyne) dioxamohydrazide dihydrate $\left(\mathrm{H} 2 \mathrm{I} \times 2 \mathrm{H}_{2} \mathrm{O}\right)$ and its metal coordination complexes; pitfalls in the use of the MTT-assay. $J$ Exp Clin Cancer Res;24:63-68.

24. Fricker S.P., Buckley R.G. (1996) Comparison of two colorimetric assays as cytotoxicity endpoints for an in vitro screen for antitumour agents. Anticancer Res;16:3755-3760.

25. Papazisis K.T., Geromichalos G.D., Dimitriadis K.A., Kortsaris A.H. (1997) Optimization of the sulforhodamine B colorimetric assay. J Immunol Methods;208:151-158.

26. Skehan P., Storeng R., Scudiero D., Monks A., McMahon J., Vistica D., Warren J.T., Bokesch H., Kenney S., Boyd M.R. (1990) New colorimetric cytotoxic assay for anticancer-drug screening. J Natl Cancer Inst;82:1107-1112.

27. Boulton S., Kyle S., Yalintepe L., Durkacz B.W. (1996) Wortmannin is a potent inhibitor of DNA double strand break but not single strand break repair in Chinese hamster ovary cells. Carcinogenesis;17:2285-2290.

28. Berenbaum M.C. (1992) Correspondence re: W. R. Greco et al., Application of a new approach for the quantitation of drug synergism to the combination of cis-diamminedichloroplatinum and 1- $\beta$-D-arabinofuranosylcytosine. Cancer Res; 50:5318-5327, 1990. Cancer Res;52:4558-4560.

29. Christodoulopoulos G., Muller C., Salles B., Kazmi R., Panasci L. (1998) Potentiation of chlorambucil cytotoxicity in B-cell chronic lymphocytic leukemia by inhibition of DNA-dependent protein kinase activity using wortmannin. Cancer Res;58:1789-1792.

30. Kartalou M., Essigmann J.M. (2001) Recognition of cisplatin adducts by cellular proteins. Mut Res;478:1-21.
31. Roos W.P., Kaina B. (2006) DNA damage-induced cell death by apoptosis. Trends Mol Med;12:440-450.

32. Tercero J.M., Matilla A., Sanjuan M.A., Moreno C.F., Martın J.D., Walmsley J.A. (2003) Synthesis, characterization, solution equilibria and DNA binding of some mixed-ligand palladium(II) complexes. Thermodynamic models for carboplatin drug and analogous compounds. Inorg Chim Acta;342:77-87.

33. Quiroga A.G., Perez J.M., Montero E.I., Masaguer J.R., Alonso C., Navarro-Ranninger C. (1998) Palladated and platinated complexes derived from phenylacetaldehyde thiosemicarbazone with cytotoxic activity in cis-DDP resistant tumor cells. Formation of DNA interstrand cross-links by these complexes. J Inorg Biochem;70:117-123.

34. Rothkamm K., Kruger I., Thompson L.H., Lobrich M. (2003) Pathways of DNA double-strand break repair during the mammalian cell cycle. Mol Cell Biol;23:5706-5715.

35. Powis G., Bonjouklian R., Berggren M.M., Gallegos A., Abraham R., Ashendel C., Zalkow L., Matter W.F., Dodge J., Grindey G., Vlahos C.J. (1994) Wortmannin, a potent and selective inhibitor of phosphatidylinositol-3-kinase. Cancer Res;54:2419-2423.

36. Schultz L.B., Chehab N.H., Malikzay A., Halazonetis T.D. (2000) p53 binding protein 1 (53BP1) is an early participant in the cellular response to DNA double-strand breaks. J Cell Biol;151:1381-1390

37. Boulton S., Kyle S., Durkacz B.W. (2000) Mechanisms of enhancement of cytotoxicity in etoposide and ionising radiationtreated cells by the protein kinase inhibitor wortmannin. Eur J Cancer;36:535-541.

38. Losada R., Riveroa M.T., Slijepcevic P., Goyanes V., Fernandez J.L. (2005) Effect of wortmannin on the repair profiles of DNA double-strand breaks in the whole genome and in interstitial telomeric sequences of Chinese hamster cells. Mut Res;570:119-128.

39. Pavon M.A., Parreno M., Leon X., Sancho F.J., Cespedes M.V., Casanova I., Lopez-Pousa A., Mangues M.A., Quer M., Barnadas A., Mangues R. (2008) Ku70 predicts response and primary tumor recurrence after therapy in locally advanced head and neck cancer. Int J Cancer;123:1068-1079.

40. Haber J.E. (2000) Partners and pathways repairing a doublestrand break. Trends Genet;16:259-264.

41. Crul M., van Waardenburg R.C.A.M., Bocxe S., van Eijndhoven M.A.J., Pluim D., Beijnen J.H., Schellens J.H.M. (2003) DNA repair mechanisms involved in gemcitabine cytotoxicity and in the interaction between gemcitabine and cisplatin. Biochem Pharmacol;65:275-282.

42. Martin L.P., Hamilton T.C., Schilder R.J. (2008) Platinum resistance: the role of DNA repair pathways. Mol Path;14:12911295.

43. Pawelczak K.S., Andrews B.J., Turchi J.J. (2005) Differential activation of DNA-PK based on DNA strand orientation and sequence bias. Nucleic Acids Res;33:152-161.

44. Lees-Miller S.P., Meek K. (2003) Repair of DNA double strand breaks by non-homologous end joining. Biochimie;85:1161-1173.

45. Dip R., Naegeli H. (2005) More than just strand breaks: the recognition of structural DNA discontinuities by DNA-dependent protein kinase catalytic subunit. FASEB J;19:704-715.

46. Frankenberg-Schwager M., Garg I., Gregus A., Neumann C., Penningers H., Pralle E., Frankenberg D.S. (2006) Wortmannin, an 


\section{Fiuza et al.}

inhibitor of DNA double-strand break rejoining, sensitizes human cells to radiation but protects against the cytotoxic effect of cisplatin: relevance for radiochemotherapy? Radiother Oncol; 78: $\$ 50$.

47. Siddik Z.H. (2003) Cisplatin: mode of cytotoxic action and molecular basis of resistance. Oncogene;22:7265-7279.

48. Koehn H., Magan N., Isaacs R.J., Stowel K.M. (2007) Differential regulation of DNA repair protein Rad51 in human tumour cell lines exposed to doxorubicin. Anticancer Drugs;18:419-425.

49. Raaphorst G.P., Li L.F., Yang D.P. (2006) Evaluation of adaptative responses to cisplatin in normal and mutant cell lines with mutations in recombination repair pathways. Anticancer Res;26:1183-1187.

50. Chirnomas D., Taniguchi T., de la Vega M., Vaidya A.P., Vasserman M., Hartman A.-R., Kennedy R., Foster R., Mahoney J., Seiden M.V., D'Andrea A.D. (2006) Chemosensitization to cisplatin by inhibitors of the Fanconi anemia/BRCA pathway. Mol Cancer Ther:5:952-961.

51. Andreassen P.R., D'Andrea A.D., Taniguchi T. (2004) ATR couples FANCD2 monoubiquitination to the DNA-damage response. Gen Dev;18:1958-1963.

52. Jacome A., Navarro S., Casado J.A., Rio P., Madero L., Estella J., Sevilla J., Badell I., Ortega J.J., Olivé T., Hanenberg H., Segovia J.C., Bueren J.A. (2006) A simplified approach to improve the efficiency and safety of ex vivo hematopoietic gene therapy in Fanconi anemia patients. Hum Gene Ther;17:1-6.

53. Jensen R., Glazer P.M. (2004) Cell-interdependent cisplatin killing by Ku/DNA-dependent protein kinase signaling transduced through gap junctions. Proc Natl Acad Sci;101:6134-6139.
54. Kruszewski M., Bouzyk E., Oldak T., Samochocka K., Fuks L., Lewandowski W., Fokt I., Priebe W. (2003) Differential toxic effect of cis-platinum(II) and palladium(II) chlorides complexed with methyl 3,4-diamine-2,3,4,6-tetradeoxy-a-L-lyxo-hexopyranoside in mouse lymphoma cell lines differing in DSB and NER repair ability. Teratog Carcinog Mutagen;23:1-11.

55. McHugh P.J., Spanswick V.J., Hartley J.A. (2001) Repair of DNA interstrand crosslinks: molecular mechanisms and clinical relevance. Lancet Oncol;2:483-490.

56. Brabec V., Kasparkova J., Vrana 0., Novakova 0., Cox J.W., Qu Y., Farrell N. (1999) DNA modifications by a novel bifunctional trinuclear platinum phase I anticancer agent. Biochem;38:67816790.

57. Jia J., Zhu F., Ma X., Cao Z.W., Li Y.X., Chen Y.Z. (2009) Mechanisms of drug combinations: interaction and network perspectives. Nat Rev Drug Discov:8:111-128.

58. Tulub A.A., Stefanov V.E. (2001) Cisplatin stops tubulin assembly into microtubules. A new insight into the mechanism of antitumor activity of platinum complexes. Int J Biol Macromol;28:191198.

59. Zeidan Y.H., Jenkins R.W., Hannun Y.A. (2008) Remodeling of cellular cytoskeleton by the acid sphingomyelinase/ceramide pathway. J Cell Biol;181:335-350.

60. Kopf-Maier P., Muhlhausen S.K. (1992) Changes in the cytoskeleton pattern of tumor cells by cispaltin in vitro. Chem Biol Interact;:82:295-316. 